\title{
Avocado crops as a floral resource for native bees of Chile
}

Víctor H. Monzón ${ }^{1}$, Patricio Avendaño-Soto ${ }^{1}$, Rodrigo O. Araujo ${ }^{1,2}$, Rubén Garrido ${ }^{1}$ and José N. Mesquita-Neto ${ }^{1,2^{*}}$ (D)

\begin{abstract}
Background: Chile is the second largest avocado producer in the world. However, there have been few studies on interactions between native bees and avocado pollination in a Chilean environment. The flowering period of avocado is very sensitive to temperature fluctuations and so environmental conditions, particularly cool temperatures, can have a strong influence on its floral behaviour. Thus, we aimed to determine whether temperature also influences bee visitation rates to avocado flowers or if this was due to the number of available flowers. Moreover, we proposed to verify the attractiveness of avocado flowers to native bees and compare flower handling time and type of floral resource collected between managed and native bees.

Methods: An avocado orchard of "Hass" cultivar located in the Mediterranean region of Chile was studied during the flowering season of 2016. The frequency of exotic and native bee species in flowers, floral phenology, and environmental temperature were analysed, and the foraging behaviours of exotic and native bee species in avocado flowers compared.
\end{abstract}

Results: Five Chilean native and two exotic species were recorded visiting avocado flowers at the studied orchard. The bees generally sought nectar rather than pollen. The European honeybee (Apis mellifera) was the most frequent flower visitor, followed by the native species Colletes cyanescens and Cadeguala occidentalis. There was a strong positive correlation between temperature and number of visits, but no significant correlation between number of open flowers and number of visits.

Conclusions: Native Chilean bees visited avocado flowers and some of them were frequent floral visitors. They generally sought for nectar rather than pollen and were as fast as honeybees handling avocado flowers. The environmental temperature plays a key role in the frequency of bees in avocado flowers. The warmer weather is related to the higher number of bees visits to avocado flowers.

Keywords: Temperature, Mediterranean, Apis mellifera, Persea americana, Pollination

\section{Background}

Avocado (Persea americana Mill., Lauraceae) is a native tree species of Central America and Mexico, and is cultivated in countries including Chile, Israel, Mexico and South Africa, as well as in many other parts of the world [1-4]. However, low avocado yields as consequence of

\footnotetext{
* Correspondence: jneiva.bio@gmail.com

'Laboratorio de Ecología de Abejas, Departamento de Ciencias Biológicas y Químicas, Facultad de Ciencias Básicas, Universidad Católica del Maule, Talca, Chile

${ }^{2}$ Centro de Investigación en Estudios Avanzados del Maule, Vicerrectoría de Investigación y Postgrado, Universidad Católica del Maule, Talca, Chile
}

the poor fruit-set remain a challenge for avocado growers in many regions [5]. Pollination is considered a determining component for the success of fruit formation in avocado orchards [6-8]. The lack of crosspollination can seriously limit fruit formation and reduce crop yields [5, 9-11].

Although avocado flowers are hermaphroditic, female and male parts are functional at different times resulting in temporal separation of the sexes [12]. Thus, avocado flowers typically open twice in a day: first as female and then as male, or vice versa [13]. Successful pollination of avocado occurs only when flowers in the female stage

(c) The Author(s). 2020 Open Access This article is licensed under a Creative Commons Attribution 4.0 International License, which permits use, sharing, adaptation, distribution and reproduction in any medium or format, as long as you give appropriate credit to the original author(s) and the source, provide a link to the Creative Commons licence, and indicate if changes were made. The images or other third party material in this article are included in the article's Creative Commons licence, unless indicated otherwise in a credit line to the material. If material is not included in the article's Creative Commons licence and your intended use is not permitted by statutory regulation or exceeds the permitted use, you will need to obtain permission directly from the copyright holder. To view a copy of this licence, visit http://creativecommons.org/licenses/by/4.0/. 
receive pollen from flowers in the male stage [14]. This flower-opening pattern is recognized as a mechanism that stresses the need for pollen vectors to facilitate cross-pollination between plants $[9,15,16]$.

Although the massive blooming of avocado involving dozens of thousands of clustered small flowers can offer a large amount of reward to attract local visitors [17], less than $1 \%$ of the flowers produce fruit at harvest [1822]. Pollinator activity in an orchard is usually not sufficient to fertilize all flowers and so yields are lower than the potential [17].

Likely pollinators of native avocado populations are species of stingless bees (Meliponinae) and wasps [3, 23]. European honeybee hives are commercially introduced to most avocado orchards during bloom to provide pollination service, which can significantly improve fruit set [8]. However, avocado did not coevolve with honeybees and has floral traits that make it less attractive to them than to its native pollinators $[3,23]$. Furthermore, honeybees reduce their visits to avocado flowers when there are other flowering plants nearby $[3,15,24,25]$. This is particularly evident in regions with a Mediterranean climate because the flowering season of avocado and the peak blooming season of local plants overlap, thereby putting them in competition for pollinators. The relative attractiveness of the avocado bloom to the honeybee could be low relative to local flowers [26, 27]. When hives of honeybees are placed in avocado orchards for pollination purposes, foragers tend to abandon the orchards to visit a nearby flowering species [17].

Chile is the second largest avocado producer in the world and its growth is related to regions with Mediterranean climate [28]. Avocado cultivation started increasing dramatically in the late 1990 s due to increasing demand from global markets and the development of new water and irrigation technology [29]. However, there are few studies evaluating the interactions of avocado with floral visitors in Chilean environments (e.g. $[30,31])$. Besides, the role of local native bees in the pollination of avocado flowers is not yet clear. Stingless bees (Meliponini), which are the main native pollinators of avocado in its region of origin (Mexico and Central America [3, 23, 32];), do not occur in Chile, and only the European honeybee (Apis mellifera) is considered for pollination of avocado by farmers.

The flowering period of avocado is very sensitive to temperature fluctuations and so environmental conditions, particularly cool temperatures, can have a strong influence on its floral behaviour [33-35]. Thus, we aimed to determine whether temperature also influences bee visitation rates to avocado flowers or if this was due to the number of available flowers. Moreover, we compared visitation rates and flower-handling times between honeybees and native bees of the Mediterranean region of Chile. Thus, we asked: (1) What is the main resource (nectar or pollen) collected by the visiting bee species of avocado flowers? (2) Are there differences in flower handling for the different resources? (3) Are native bee species efficient in handling avocado flowers compared to exotic species?

\section{Methods}

\section{Study area and studied species}

The study took place in an avocado orchard of "Hass" cultivar located in Hijuelas $\left(32^{\circ} 48^{\prime} 12.8^{\prime \prime} \mathrm{S} 71^{\circ} 08^{\prime} 29.1^{\prime \prime}\right.$ W), Valparaíso Region, Chile, between 16 and 29 September of 2016. The Hijuelas orchard encompasses 227 ha with 68 trees/ha and 10 honeybee hives/ha. The orchard contains two cultivars: "Hass" (A-type avocado) and "Edranol" (B-type avocado). Hijuelas is in the Mediterranean bioclimatic zone, which is characterized by a rainy winter, between May and August, and a long dry period, between September and April [36]. The mean annual temperature was $14.9{ }^{\circ} \mathrm{C}$, and the mean annual precipitation was $353 \mathrm{~mm}$ in 2016 [37]. The surroundings of the avocado orchard are composed mostly of fragments of native vegetation. The major vegetation formation in the area is Matorral arborescente esclerófilo mediterráneo interior, an open forest formation dominated by tall shrubs like Porlieria chilensis or Cordia decandra and some trees species like Quillaja saponaria and Lithraea caustica [38].

\section{Frequency of bees in flowers, amount of flowers and environmental temperature}

Visits of bees to avocado flowers, the amount of flowers (number of open flowers/day) and environmental temperature were evaluated during 13 consecutive days of fieldwork (16-29 September 2016). Thirty "Hass" cultivar plants (three rows of 10 trees each) were randomly chosen and assigned an identification number. Three trained observers recorded all bees that contacted floral parts during four time intervals per day $(9-10 \mathrm{~h}, 12-13$ h, 15-16 h, 18-19 h). The observers counted all flowervisiting insects throughout the entire perimeter of the treetop $\left(360^{\circ}\right)$ for a period of $120 \pm 15 \mathrm{~s}$ per tree. Thus, we sampled in a similarly the sunny and shaded side of the plant. In this way, taxa of visiting bees and their relative frequency in avocado flowers were determined. The number of open flowers and floral buds of three branches of each of the 10-labelled trees were counted. Environmental temperature was recorded during four time intervals $(9-10 \mathrm{~h}, 12-13 \mathrm{~h}, 15-16 \mathrm{~h}, 18-19 \mathrm{~h})$ during the 13-days of fieldwork using a multi-thermometer. We analysed whether the bee frequency in avocado flowers was influenced by the number of open flowers/ day and the average daily temperature. 


\section{Bees foraging behaviour in flowers}

The foraging behaviour of visiting bees in avocado flowers was recorded using a voice recorder in 30 "Hass" cultivar plants (three rows of 10 trees each) randomly chosen. The taxonomic identification of each individual bee, the type of floral resource collected (pollen or nectar) and the time spent visiting individual flowers (handling time) were recorded. We distinguish bees visits to collect pollen and/or nectar according to the foraging behaviour described by Is-Am \& Eisikowitz [24]. We do not take pollen or nectar samples from the bees, therefore the analyses are based on the foraging behaviour of the bees. When bee identification was not possible in the field, specimens were caught with an entomological net and identified later in the laboratory. Average flower handling time was compared between exotic and native bees.

\section{Statistical analysis}

Principal Component Analysis (PCA) assessed relationships among the variables of temperature, number of open flowers and frequency of floral visits in the stats package of $\mathrm{R}$ version 3.3.3 [39]. The relationship among frequency of floral visits and the number of open flowers and frequency of floral visits by bees was analyzed by Spearman rank correlation $\left(r_{s}\right)$. A Generalized Linear Mixed Model (GLMM, Negative Binomial distribution) was used to determine which type of resource (fixed effect) was more collected by bees in avocado flowers; bee species was included as random effect. A GLMM (Negative Binomial distribution) was also used to compare visitation frequencies and flower handling times of bee species (fixed effects); the sampling date was included as random effect. The GLMMs were performed using the function glmer.rb of the R package lme4.

\section{Results}

Seven bee species were recorded visiting avocado flowers at the Hijuelas orchard in September 2016 (Fig. 1b): five native Chilean species-Colletes cyanescens (Haliday), Cadeguala occidentalis (Haliday), Callistochlora chloris (Spinola), Caupolicana gayi Spinola and Centris nigerrima (Ruiz); and two exotic species-Apis mellifera Linnaeus and Bombus terrestris (Linnaeus). Apis mellifera, the European honeybee, was the most frequent bee in the studied avocado flowers, followed by the two native species Colletes cyanescens and Cadeguala occidentalis. The other bee species were rare in avocado flowers $\left(x^{2}=\right.$ 502.38, d.f. $=7, p \leq 0.001$; Fig. 1b).

\section{Flower resources and handling time}

The seven species of bees were observed collecting nectar and pollen in the avocado flowers. The native and exotic bee species spent similar time handling the

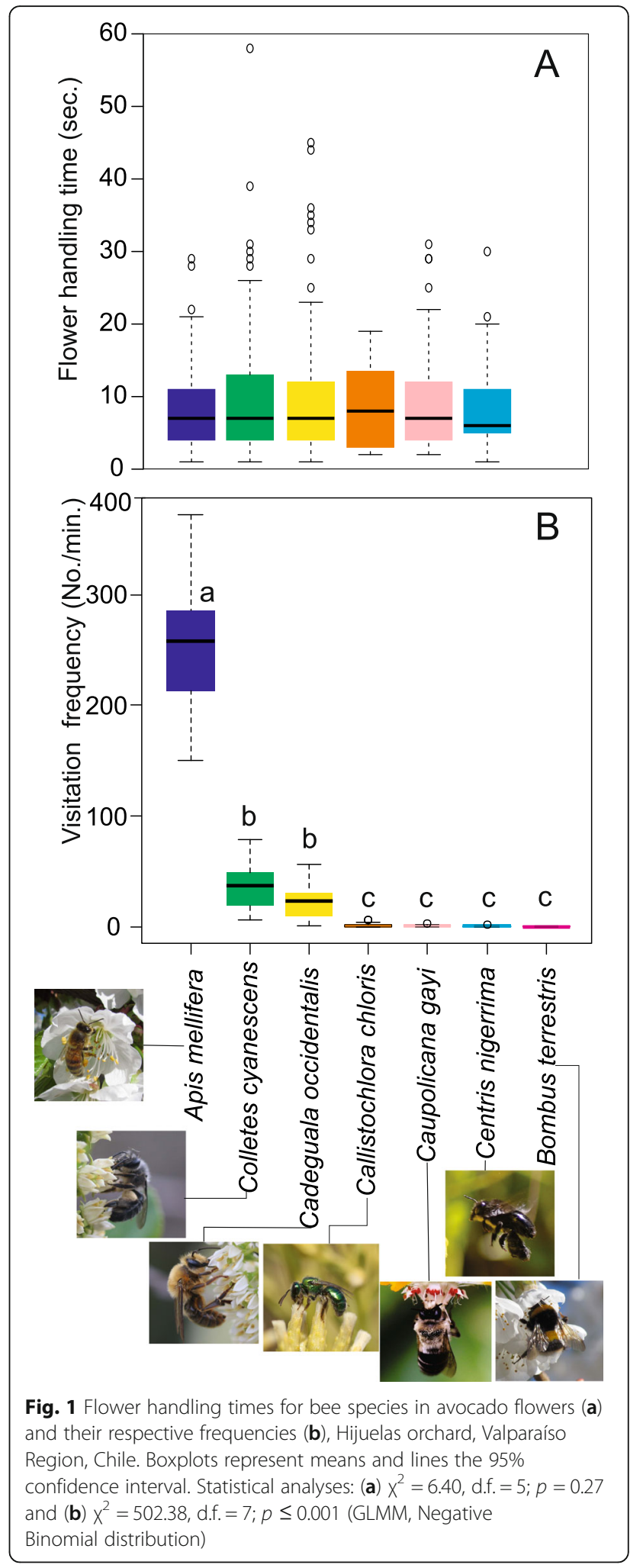

avocado flowers ( $x^{2}=6.40$, d.f. $=5, p=0.27$; Fig. 1a). Foraging honeybees visited about 7.5 avocado flowers per min, or about 450 flowers per hour, while native bees 
species visited between 8.8 and 9.6 flowers per min or 375-409 flowers per hour.

The bees collected nectar and/or pollen during visits to single flowers or they collected nectar and pollen during different visits to different flowers. Flower handling time did not differ significantly between extracting nectar and extracting pollen, and handling time to gather nectar plus pollen did not different from that for collecting nectar or pollen in the same flower (Fig. 2).

The type of floral resource collected varied among bee species. The native bees Colletes cyanescens, Cadeguala occidentalis and Caupolicana gayi mainly foraged for nectar during visits to avocado flowers (Fig. 3). Apis mellifera collected proportionally less nectar, and frequently landed on flowers without effectively collecting any resource. Bees of Callistochlora chloris mostly collected pollen and nectar at the same visit. Bees of Centris nigerrima generally landed on avocado flowers without collecting a resource (Fig. 3).

\section{Temperature and number of open flowers}

The frequency of bees in avocado flowers was related more to the temperature than to the number of open flowers (Fig. 4). There was a strong positive correlation between temperature and number of visits $\left(r_{s}=0.82\right.$, $p \leq 0.001$ ), but no significant correlation between number of open flowers and number of visits $\left(\mathrm{r}_{\mathrm{s}}=047, p=\right.$ 0.11; Fig. 5). No correlation was found between environmental temperature and the number of open avocado flowers $\left(r_{s}=0.32, p=0.23\right)$. Higher bee visitation rates were related to higher temperatures $\left(19-22^{\circ} \mathrm{C}\right)$.

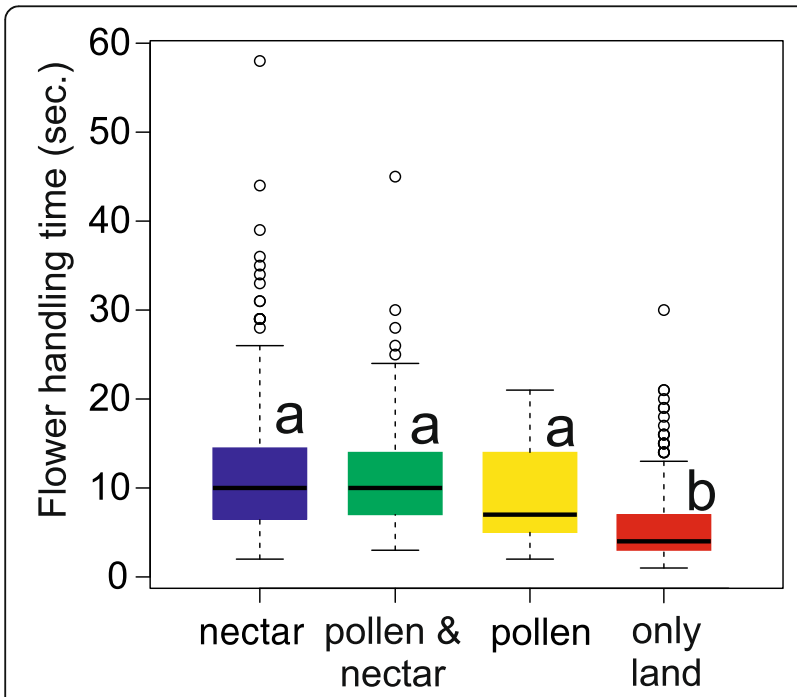

Fig. 2 Handling time and floral resource(s) collected by bees in avocado flowers, Hijuelas orchard, Valparaíso Region, Chile. Statistical analysis: $x^{2}=192.1$, d.f. $=4 ; p \leq 0.001$, GLMM (Negative

Binomial distribution)

\section{Discussion}

Our results indicate that temperature might affect the frequency of bee visits to avocado flowers, with higher frequencies being related to higher temperatures in the Mediterranean region of Chile. Surprisingly, the frequency of bees in avocado flowers is not simply affected by the amount of open flowers. Accordingly, other intrinsic characteristics of the avocado flower or aspects related to the bees' own sensitivity to cold weather could be more important variables affecting the visits. In fact, the temperature has been related to many physiological and morphological functions of the avocado flower. For example, avocado flowers are sensitive to cool temperatures, which can affect the temporal separation of male and female stages [40]. When air temperatures are below $20^{\circ} \mathrm{C}$, some overlapping of receptive stigmas and anther dehiscence occurs, which may lead to some pollination within an individual tree [33-35, 41]. Colder temperature also affects pollen tube growth, with $25^{\circ} \mathrm{C}$ being the optimum temperature [34, 41, 42]. On the other hand, bees prefer to visit parts of the tree warmer and more exposed to sunlight, where also there is a greater number of flowers, and avoiding the shaded and colder parts [31]. Therefore, we assumed that the frequency of bees in avocado flowers is not directly affected by the amount of open flowers, but due to other morphological and physiological characteristics of the avocado flower or of the bees sensitive to the cold weather.

Apis mellifera is the only pollinator managed for commercial proposes in Chile. Indeed, the European honeybee plays a leading role in avocado pollination $[8,21]$. Nonetheless, avocado flowers were also visited by the local bee community in Chile, some of which were frequent flower visitors (see also [30, 31]). However, there is no evidence supporting these native bees have specialized interactions with avocado crops. Contrariwise, these bees are considered polylectic, generalists visitors that collect pollen from both related and unrelated plant species, including natives and cultivated [43-47]. Therefore, it is likely that the floral visitors of avocado are shared with local native and cultivated vegetation. Consequently, the richness and abundance of bees that visit the avocado flowers are subject to the taxonomic composition, phenological fluctuations and floral morphophysiology of surrounding flowering plants, similarly to what occurs with honeybee [3, 15, 24-26].

Furthermore, honeybees and native bees were found to be equally fast at handling avocado flowers. Honeybees and the two most frequent native bees (Colletes cyanescens and Cadeguala occidentalis) fed on nectar and pollen in avocado flowers, however, visiting bees searched more for nectar than pollen. Many studies have 


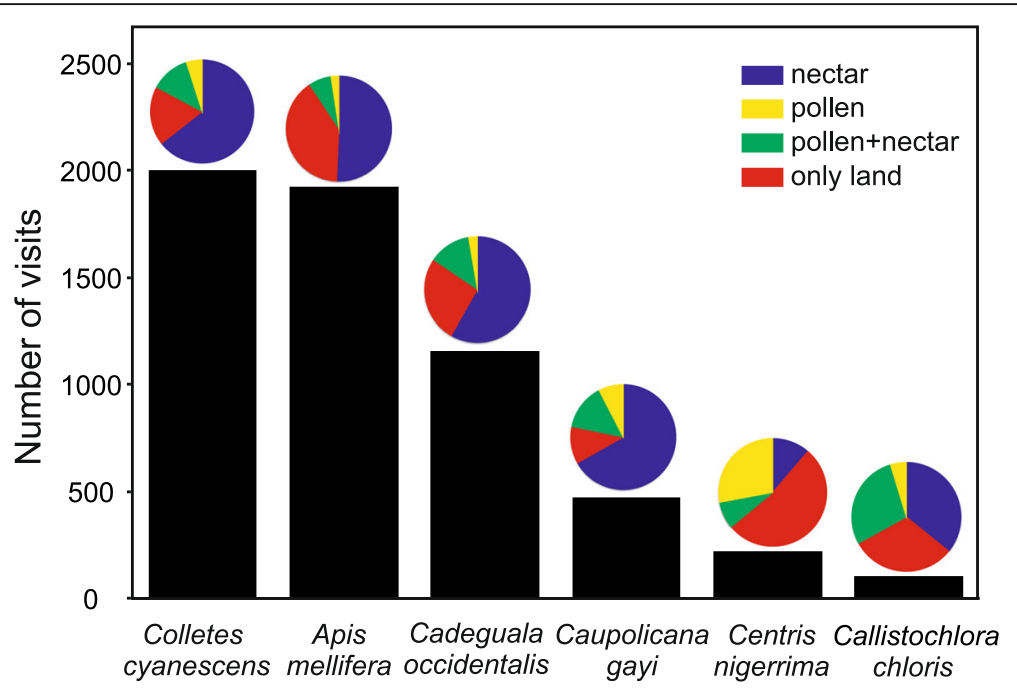

Fig. 3 Floral resources collected by bee species in avocado flowers, Hijuelas orchard, Valparaíso Region, Chile. Black bars represent the number of visits recorded per bee species while corresponding pie charts shows the resource(s) collected during these visits (nectar, pollen, pollen and nectar or only land). We considered "only land" to be when a bee landed on a flower and did not collect any resource

suggested that nectar-feeding bees achieve more efficient pollination of avocado because they actively move between both male- and female-stage flowers, while pollen-gathering bees visit male-stage flowers more frequently $[8,21,24,30,32]$;). Therefore, based on foraging behaviour, native species and honeybees can be equally probable pollinators of avocado plants.

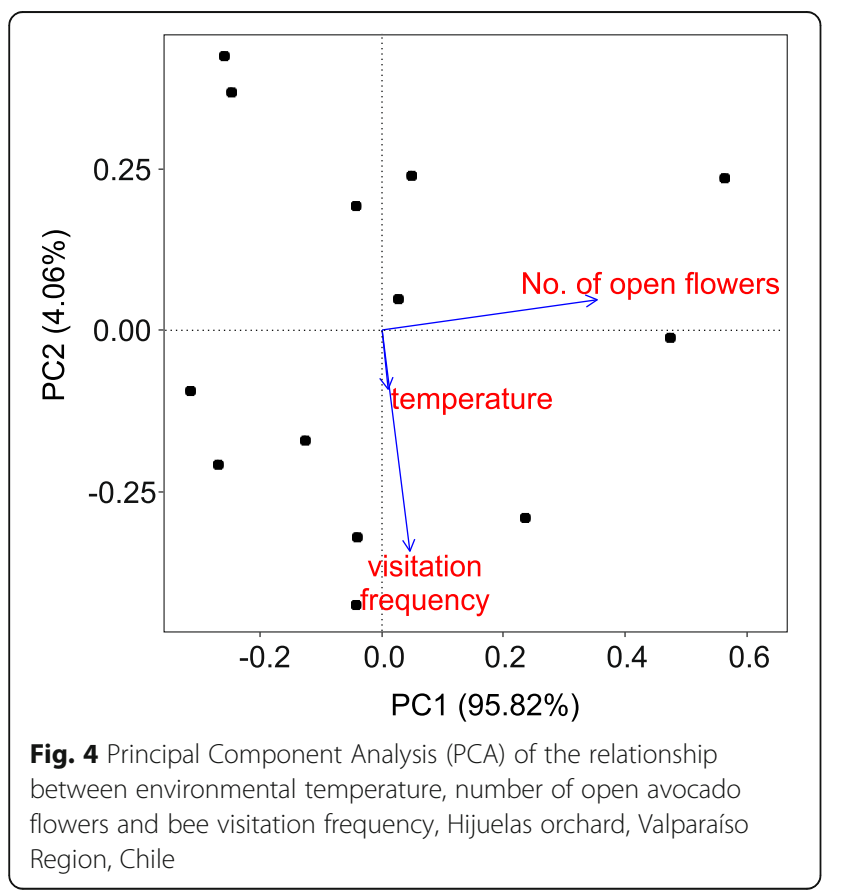

However, there are few studies clarifying the role of native bee species in relation to exotic species in avocado pollination (e.g. [3, 30-32]). These studies consider honeybees and some native bees (not all) potentially efficient pollinators of this crop. However, other studies argue that the honeybees are the most frequent flower visitors (representing until 92.9\% of all visits), usually carry avocado pollen on their body, and generally deposit intraspecific pollen in the stigmas $[8,48]$. Because of that, honeybees are considered the most efficient pollinators. However, there are many more studies focusing only on the pollination effectiveness of honeybees than those that also include other local visitors. Therefore, it is still unclear whether native bees can function as supplementary or alternative pollinators when honeybee frequency reduces in flowers.

Moreover, particularities involving avocado pollination impose requirements to pollination studies. Avocado plants are characterized as having low fruit set, with values worldwide varying from 1 to 200 fruit per 100,000 flowers $[10,20,21,49]$. Fruit set for the "Hass" cultivar in Chile can reach as low as $0.01 \%$, or one fruit per 10,000 flowers [49]. Besides, the temporal separation of the sexes in flowers [12] requires additional attention by researchers, including crosspollination treatments between plants in male and female stages. Due to this, pollination experiments (e.g., breeding system and fruit set, pollen flow, pollination effectiveness) on avocado require employing a huge amount of flowers to achieve a satisfactory number of samples and replicates. Despite these 

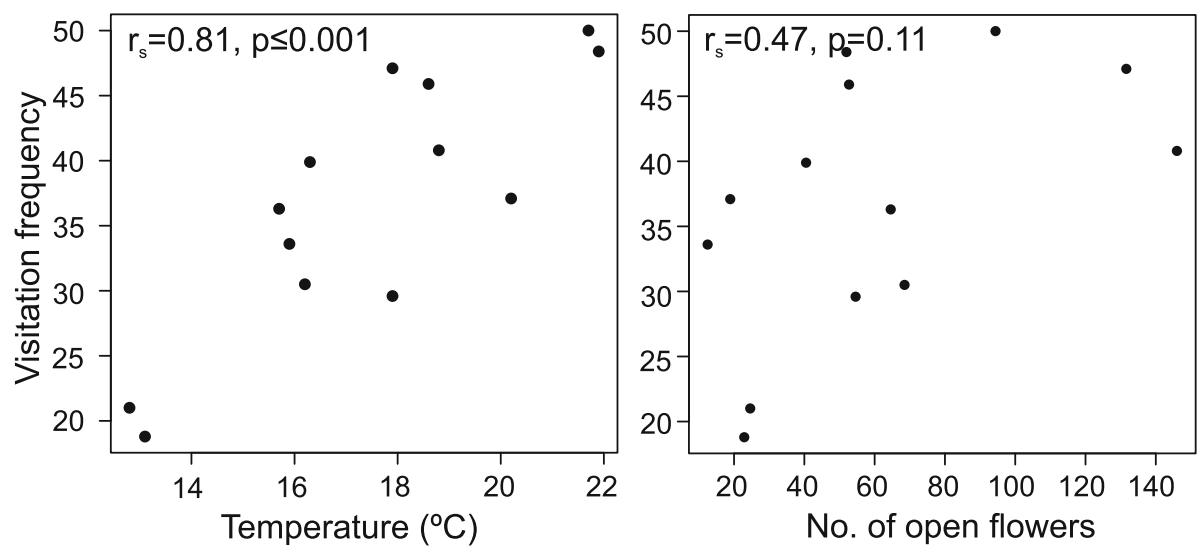

Fig. 5 Spearman rank correlation $\left(r_{s}\right)$ between mean visitation frequency of visiting bees and temperature (left side graphic) and number of open flowers (right side graphic)

challenges, studies of pollination efficiency could reveal the role of Chilean native bees, in relation to exotics, in pollinating avocado flowers.

\section{Conclusions}

The number of open flowers was little correlated to the frequency of bees in avocado trees. On the other hand, the environmental temperature plays a key role in the frequency of bees in avocado flowers. The warmer weather is related to the higher number of bees visits to avocado flowers. In addition to the honeybees, the native Chilean bees visited avocado flowers. Some of these bees were frequent floral visitors of the studied avocado orchard, and generally sought nectar rather than pollen. The native and exotic bees were equally fast at handling avocado flowers to collect resources (pollen and/or nectar).

\section{Abbreviations}

PCA: Principal Component Analysis; GLMM: Generalized Linear Mixed Model; $r_{s}$ : Spearman rank correlation

\section{Acknowledgements}

We thank Luisa Ruz Escudero of the Pontificia Universidad Católica de Valparaiso for identifying bees species and two anonymous reviewers for their comments, which improved the manuscript and Agricola Ocoa Ltda. for providing access to the study area.

\section{Authors' contributions}

VHG, RG and JNM-N conceived the ideas and designed methodology; VHG, PAS, RG collected the data; JNM-N and ROA analyzed the data; VHG, JNM-N, ROA and RG led the writing of the manuscript. All authors contributed critically to the drafts and gave final approval for publication.

\section{Funding}

This work was funded by Fondo de Innovación Para la Competitividad Región del Maule [FIC-30387076-0].

\section{Availability of data and materials}

The datasets used and/or analysed during the current study are available from the corresponding author on reasonable request.

\section{Competing interests}

The authors declare that they have no competing interests.

Received: 17 December 2019 Accepted: 13 May 2020

Published online: 01 June 2020

\section{References}

1. Chen H, Morrell PL, Ashworth VE, De La Cruz M, Clegg MT. Tracing the geographic origins of major avocado cultivars. J Hered. 2008;100(1):56-65 https://doi.org/10.1093/jhered/esn068.

2. Galindo-Tovar ME, Ogata-Aguilar N, Arzate-Fernández AM. Some aspects of avocado (Persea americana mill.) diversity and domestication in Mesoamerica. Genet Resour Crop Evol. 2008;55(3):441-50 https://doi.org/10. 1007/s10722-007-9250-5

3. Ish-Am G, Barrientos-Priego F, Castañeda-Vildozola A, Gazit S. Avocado (Persea americana mill.) pollinators in its region of origin. Rev Chapingo Ser Hort. 1999:5:137-43.

4. Bergh BO. Avocado research in Israel. Calif Avocado Soc Yearb. 1975;58:10326.

5. Bergh BO. Reasons for low yields of avocados. Calif Avocado Soc Yearb. 1967;51:161-72.

6. Papademetriou MK. Some aspects of the flower behaviour, pollination and fruit set of avocado (Persea americana Mill.) in Trinidad. Calif Avocado Soc Yearb. 1976;60:106-53.

7. Stout AB. The pollination of avocados. Fla Agric Exp Stn Bull. 1933;257:1-44.

8. Vithanage $V$. The role of the European honeybee (Apis mellifera) in avocado pollination. J Hortic Sci. 1990;56:81-6 https://doi.org/10.1080/00221589.1990. 11516033.

9. Carabalí-Banguero D, Montoya-Lerma J, Carabalí-Muñoz A. Efecto de la exclusión de insectos visitantes florales en el cuajado de frutos de Persea americana (Lauraceae) cv. Hass. Acta Zool Mex. 2018;34(1):1-9 https://doi. org/10.21829/azm.2018.3412121.

10. Evans LJ, Goodwin RM, McBrydie HM. Factors affecting 'Hass' avocado (Persea americana) fruit set in New Zealand. N Z Plant Prot. 2010;63:214-8.

11. Gazit S. Pollination and fruit set of avocado. In: Proceedings of the first international tropical fruit short course: the avocado. Gainesville: University of Florida; 1977.

12. Stout AB. Avocado studies-pollination and setting of fruit. Fla Grower. 1925; 31(4):6-7.

13. Ish-Am G, Lahav E. Evidence for a major role of honeybees (Apis mellifera) rather than wind during avocado (Persea americana mill.) pollination. J Hortic Sci Biotechnol. 2011;86:589-94 https://doi.org/10.1080/14620316. 2011.11512808.

14. Sedgley M. Reduced pollen tube growth and the presence of callose in the pistil of the male floral stage of the avocado. Sci Hortic. 1977;7(1):27-36 https://doi.org/10.1016/0304-4238(77)90040-1.

15. Ish-Am G, Eisikowitch D. Mobility of honey bees (Apidae, Apis mellifera L.) during foraging in avocado orchards. Apidologie. 1998;29:209-19 https:// doi.org/10.1051/apido:19980301. 
16. McGregor SE. Insect pollination of cultivated crop plants. In: agriculture handbook no. 496. Washington DC: United States Department of Agriculture Agricultural Research Service; 1976.

17. Ish-Am G. Avocado pollination: A review. In: New Zealand and Australia Avocado Grower's Conference. Tauranga, New Zealand; 2005. http:// citeseerx.ist.psu.edu/viewdoc/download?doi=10.1.1.632.3600\&rep=rep1 \&type=pdf. Accessed 20 May 2019.

18. Garner LC, Ashworth VE, Clegg MT, Lovatt CJ. The impact of outcrossing on yields of 'Hass' avocado. J Am Soc Hortic Sci. 2008;133(5):648-52 https://doi. org/10.21273/JASHS.133.5.648.

19. Inoue H, Takahashi B. Studies on the bearing behavior and yield composition of the avocado tree. J Jpn Soc for Hortic Sci. 1990;59(3):487501.

20. Lahav E, Zamet D. Flowers, fruitlets and fruit drop in avocado trees. Rev Chapingo Ser Hort. 1999;5:95-100.

21. Peña JF, Carabalí A. Effect of honey bee (Apis mellifera L.) density on pollination and fruit set of avocado (Persea americana mill.) cv. Hass. J Apic Sci. 2018;62(1):5-14 https://doi.org/10.2478/jas-2018-0001.

22. Sedgley M. Anatomical investigation of abscissed avocado flowers and fruitlets. Ann Bot. 1980;46(6):771-7 https://doi.org/10.1093/oxfordjournals. aob.a085974.

23. Castañeda-Vildózola A, Equihua-Martínez A, Valdés-Carrasco J, BarrientosPriego AF, Ish-Am G, Gazit S. Insectos polinizadores del aguacatero en los estados de México y Michoacán. Rev Chapingo Ser Hort. 1999;5:129-36.

24. Ish-Am G, Eisikowitch D. The behaviour of honey bees (Apis mellifera) visiting avocado (Persea americana) flowers and their contribution to its pollination. J Apic Res. 1993;32:175-86 https://doi.org/10.1080/00218839. 1993.11101303.

25. Ish-Am G, Regev Y, Peterman Y, Lahav E, Degani C, Elbatzri R, Gazit S. Improving avocado pollination with bumblebees: 3 seasons summary. Calif Avocado Soc Yearb. 1998;82:119-35

26. Afik O, Dag A, Shafir S. The effect of avocado (Persea americana) nectar composition on its attractiveness to honey bees (Apis mellifera). Apidologie. 2006;37(3):317-25 https://doi.org/10.1051/apido:2005064.

27. Ish-Am G, Eisikowitch D. Low attractiveness of avocado (Persea americana mill.) flowers to honeybees (Apis mellifera L.) limits fruit set in Israel. J Hortic Sci Biotechnol. 1998;73:195-204 https://doi.org/10.1080/14620316.1998. 11510965.

28. Schaffer BA, Wolstenholme BN, Whiley AW. The avocado: botany, production and uses. 2nd. ed. New York: CABI Publishing; 2013.

29. Budds J. Power, nature and neoliberalism: the political ecology of water in Chile. Singap J Trop Geogr. 2004;25(3):322-42 https://doi.org/10.1111/j.01297619.2004.00189.x

30. De la Cuadra S. Determinación de la actividad polinizadora de la abeja (Apis mellifera) en la polinización del palto en la Zona Central de Chile. In: Proceedings VI World Avocado Congress. Viña Del Mar, Chile; 2007. http:// www.avocadosource.com/WAC6/es/Extenso/3d-124.pdf. Accessed 20 May 2019.

31. Valdés CA. Evaluacion de la actividad de Apis mellifera $\mathrm{L}$. y otros insectos asociados a la floracion del palto (Persea americana Mill.) cv. Hass en dos localidades de la Quinta region (Quillota y La Ligua): Undergraduate thesis: Universidad Catolica de Valparaiso; 2002.

32. Can-Alonzo C, Quezada-Euán JJG, Xiu-Ancona P, Moo-Valle H, ValdovinosNunez GR, Medina-Peralta S. Pollination of 'criollo'avocados (Persea americana) and the behaviour of associated bees in subtropical Mexico. J Apic Res. 2005;44(1):3-8 https://doi.org/10.1080/00218839.2005.11101138.

33. Lesley JW, Bringhurst RS. Environmental conditions affecting pollination of avocados. Calif Avocado Soc Yearb. 1951;35:169-73.

34. Sedgley M, Annells CM. Flowering and fruit-set response to temperature in the avocado cultivar 'Hass'. Sci Hortic. 1981;14(1):27-33 https://doi.org/10. 1016/0304-4238(81)90075-3.

35. Stout AB. A study in cross pollination of avocados in southern California. Calif Avocado Assoc Ann Rpt. 1923:8:29-45.

36. Elórtegui S, Moreira A. Parque Nacional la Campana. Origen de una reserva de la biosfera en Chile central. Santiago: Taller La Era; 2002.

37. Center for Climate and Resilience Research Database (CR2). 2020. http:// explorador.cr2.cl/. Accessed 05 Mar 2020.

38. Luebert F, Pliscoff P. Sinopsis bioclimática y vegetacional de Chile. Santiago: Editorial Universitaria; 2006
39. R Core Team. R: A language and environment for statistical computing. $\mathrm{R}$ Foundation for Statistical Computing. 2017. Vienna, Austria. https://www. Rproject.org.

40. Pattemore D, Buxton MN, Cutting BT, McBrydie H, Goodwin M, Dag A. Low overnight temperatures associated with a delay in 'Hass' avocado (Persea americana) female flower opening, leading to nocturnal flowering. J Pollinat Ecol. 2018;23(14):127-35 https://doi.org/10.26786/1920-7603\%282018\%2912.

41. Sedgley M, Grant WJR. Effect of low temperatures during flowering on floral cycle and pollen tube growth in nine avocado cultivars. Sci Hortic. 1983; 18(3):207-13 https://doi.org/10.1016/0304-4238(83)90023-7.

42. Sedgley $M$. The effect of temperature on floral behaviour, pollen tube growth and fruit set in the avocado. J Hortic Sci. 1977;52:135-41 https://doi. org/10.1080/00221589.1977.11514739.

43. González AV, Murúa M, Ramírez PA. Temporal and spatial variation of the pollinator assemblages in Alstroemeria ligtu (Alstroemeriaceae). Rev Chil Hist Nat. 2014;87(1):5 https://doi.org/10.1186/0717-6317-87-5.

44. Medel R, González-Browne C, Salazar D, Ferrer P, Ehrenfeld M. The most effective pollinator principle applies to new invasive pollinators. Biol Lett. 2018;14(6):20180132 https://doi.org/10.1098/rsbl.2018.0132.

45. Packer L, Zayed A, Grixti JC, Ruz L, Owen RE, Vivallo F, Toro H. Conservation genetics of potentially endangered mutualisms: reduced levels of genetic variation in specialist versus generalist bees. Biol Conserv. 2005:19(1):195202 https://doi.org/10.1111/j.1523-1739.2005.00601.x.

46. Smith-Ramírez C, Martinez P, Nunez M, González C, Armesto JJ. Diversity, flower visitation frequency and generalism of pollinators in temperate rain forests of Chiloé Island, Chile. Bot J Linn Soc. 2005;147(4):399-416 https:// doi.org/10.1111/j.1095-8339.2005.00388.x.

47. Zayed A, Packer L, Grixti JC, Ruz L, Owen RE, Toro H. Increased genetic differentiation in a specialist versus a generalist bee: implications for conservation. Conserv Genet. 2005;6(6):1017-26 https://doi.org/10.1007/ s10592-005-9094-5.

48. Read SFJ, Howlett BG, Jesson LK, Pattemore DE. Insect visitors to avocado flowers in the Bay of Plenty, New Zealand. N Z Plant Prot. 2017;70:38-44 https://doi.org/10.30843/nzpp.2017.70.25.

49. Cossio-Vargas LE, Salazar-Garcia S, Gonzalez-Duran IJ, Medina-Torres R. Algunos aspectos reproductivos del aguacate 'Hass' en clima semicálido. In: Proceedings VI World Avocado Congress. Viña del Mar, Chile; 2007. http:// www.avocadosource.com/WAC6/es/Extenso/3d-151.pdf. Accessed 21 May 2019

\section{Publisher's Note}

Springer Nature remains neutral with regard to jurisdictional claims in published maps and institutional affiliations.

Ready to submit your research? Choose BMC and benefit from:

- fast, convenient online submission

- thorough peer review by experienced researchers in your field

- rapid publication on acceptance

- support for research data, including large and complex data types

- gold Open Access which fosters wider collaboration and increased citations

- maximum visibility for your research: over $100 \mathrm{M}$ website views per year

At BMC, research is always in progress.

Learn more biomedcentral.com/submissions 